\title{
KENTSEL YAŞAM KALITESI ÜZERİNE KARŞILAŞTIRMALI BİR INCELEME: SAMSUN ONDOKUZ MAYIS ÜNIVERSITESI GÜZEL SANATLAR KAMPÜSÜ ÖRNEĞİ
}

\author{
A COMPARATIVE STUDY ON QUALITY OF URBAN LIFE: THE CASE OF SAMSUN \\ ONDOKUZ MAYIS UNIVERSITY FINE ARTS CAMPUS
}

\author{
Saim Can BERITAN ${ }^{1}$ - Yeliz EMECEN ${ }^{2}$
}

\begin{abstract}
$\ddot{\mathbf{O z}}$
Dünya nüfusunun yarısından fazlasının kentlerde yaşamını sürdürdüğ̈̈ gerçeği, yaşam kalitesinin neden günümüzde kent çalışmalarının ana tartışma konularından biri olarak görünür olduğu sorusunun anlaşılması bakımından önemlidir. Ayrıca yakın gelecekte her beş insandan birinin nüfusu en az 1 milyon olan kentlerde yaşayacağına yönelik öngörüler, kentsel yaşam kalitesi olgusunun çok daha önemli bir ölçüt olarak referans alınma potansiyelini ortaya koymaktadır. Bununla birlikte öznesi insan olan ve farklı disiplinlerin kendine özgü yöntemlerle ele aldığı yaşam kalitesi konusu, en genel manada, dışsal (nesnel) koşulların onu deneyimleyen insanlar tarafından algılanma (öznel) biçimi ve neticesinde yorumlanması olarak tanımlanabilir. Bu bakış açısından yola çıkarak ekonomik, sosyolojik ve kültürel göstergeler bağlamında Atakum ve İlkadım gibi Samsun'un iki merkez ilçesinin kesişme noktasında bulunan Ondokuz Mayıs Üniversitesi Güzel Sanatlar Kampüsünde öğrenim gören dört farklı fakülteden 136 lisans öğrencisiyle - kentsel yaşam kalitesi üzerine görüş̧meler yapılmıştır. Elde edilen bulgular ise, cinsiyet ve fakülte farklılaşmasına dayalı iki boyutlu değişken üzerinden değerlendirilerek karşılaştırmalı olarak yorumlanmıştır. Sonuç olarak, bu çalışmada nesnel yaşam kalitesi göstergelerinin örneklem grubu tarafindan Samsun ölçeğinde nasıl algılandığının anlamlandırılması amaçlanmıştır.
\end{abstract}

Anahtar Kelimeler: Yaşam Kalitesi, Kentsel Yaşam Kalitesi, Samsun, Ondokuz Mayıs Üniversitesi, Güzel Sanatlar Kampüsü.

\begin{abstract}
More than half of the world population is urban dwellers and this fact is significant to understand why quality of life is prominent among the issues of debate in urban studies. Moreover, the predictions that in the near future, one in every five people will be living in cities with a population over 1 million demonstrate the potential of the quality of urban life phenomenon to be referred as a more important criterion. Quality of life phenomenon, whose object is the human and is approached with distinct methods by different disciplines, can be defined very broadly as the perception and interpretation of the external (objective) conditions by humans (subjective) who experience it. Based upon this viewpoint, interviews have been conducted on quality of urban life with 136 undergraduate students from 4 different faculties located at the Ondokuz Mayıs University Fine Arts Campus, which is at the intersection of Atakum and Ilkadım, two central neighborhoods according to economic, sociological and cultural indicators. The findings have been evaluated using a two-dimensional variable based on gender and faculty distinctions and have been interpreted comparatively. In conclusion, this study aims to explicate how objective quality of life indicators are perceived by the sample group within the scale of Samsun.
\end{abstract}

Keywords: Quality of Life, Quality of Urban Life, Samsun, Ondokuz Mayıs University, Fine Arts Campus.

\footnotetext{
${ }^{1}$ Dr.Öğr.Üyesi, Ondokuz mayıs üniversitesi, mimarlık fakültesi, saim.beritan@omu.edu.tr, Orcid: 0000-00030038-6452

${ }^{2}$ Arş. Gör., Ondokuz Mayıs Üniversitesi, Mimarlık Fakültesi, Şehir ve Bölge Planlama Bölümü, yeliz.emecen@omu.edu.tr, Orcid: 0000-0002-6498-6804
} 


\section{GİRIŞ}

Yaşam kalitesi son yıllarda sıkça referans verilen ve literatürde ağırlık kazanan bir kavram olarak öne çıkmaktadır. Kavram o kadar geniş bir yelpaze içerisinde disiplinlerarası bir perspektifle ele alınmaktadır ki farklı anlamsal düzlemlerde kullanılmaktadır (Beritan, 2014: 103). Yaygın bir kavramsal kullanım alanına yerleşen yaşam kalitesi ile ilgili olarak bu bağlamda genel bir tanımlama yapma güçlügünden söz edilebilir. Bununla birlikte mutluluk ve tatmin gibi son derece değişken duygu durumlarıyla bağıntılı bir kavramsal olarak yaşam kalitesinin içerdiği görecelilik, yaşam kalitesine dair net bir tanım yapılmasını zorlaştıran bir başka etkendir (Das, 2008: 298). Tüm bu tanımsal karmaşaya rağmen yaşam kalitesinin en genel anlamıyla yaşama dair biçimsel ve/veya durumsal bir standardı ifade ettiği söylenebilir (Picardo-Muňiz, 2011: 365). Daha dar anlatımla yaşam kalitesi, insanın fiziksel çevreyle olan etkileşimi sonucu ortaya çıkan duyusal ve algısal durumunu anlatmaktadır (Marans ve Stimson, 2011: 1; Massam, 2002: 145).

Daha önce değinildiği üzere yaşam kalitesi oldukça geniş bir akademik alan içerisinde tartışılmakta ve bu kapsamda farklı yöntemler ve göstergeler 1şığında çok boyutlu bir yaklaşımla ele alınmaktadır (Brown vd., 2004: 8). Kent çalışmaları literatüründe de yaygın olarak kullanılan yaşam kalitesi, salt kentsel yaşanabilirlik olgusunu anlamlandırma çabasının bir tezahürü olmamakta, ayrıca insanların kentlerdeki tatmin ve memnuniyet algılarını da anlamaya yönelik bir kavram olarak referans alınmaktadır (Marans ve Stimson, 2011: 4).

Kentsel yaşam kalitesi çalışmalarında ölçümlemeler için kullanılan göstergeler; nesnel (objektif), öznel (subjektif) ve bütünleşik olmak üzere ağırlıkla üç temel yaklaşım üzerinden yapılmaktadır (Lotfi vd, 2011: 234; Diener ve Suh, 1997: 198). Marans ve Stimson (2011: 4), kentsel yaşam kalitesinin mutlak ölçüsünün tek başına nesnel gerçeklikler olamayacağını belirterek insanların algılama boyutu ve algıladığı çevresel faktörleri yorumlama biçimine bu doğrultuda dikkat çekerek, öznel ve bütünleşik göstergelerin kentsel yaşam kalitesi araştırmalarındaki önemine vurgu yapmaktadırlar. Bu yaklaşımdan hareketle çalışma, yaşam kalitesinin temel olarak insanların nesnel gerçeklik karşısındaki öznel algılama biçimleri olduğuna yönelik tanımsal zemin üzerine oturtulmuş (Türkoğlu vd, 2011: 218), sonrasında da nesnel göstergeler kullanılarak kentsel yaşam kalitesinin örneklem tarafindan nasıl algılandığının anlamlandırılması amaçlanmıştır. Bu bağlamda Mimarlık Fakültesinin de içinde yer aldığı Ondokuz Mayıs Üniversitesi Güzel Sanatlar Kampüsünde lisans düzeyinde eğitim verilen birimlerde okuyan öğrencilerin kentsel yaşam kalitesi algılarının betimlendirilmesine yönelik analizler yapılmıştır.

Makalenin ilk bölümünde yaşam kalitesi ve kentsel yaşam kalitesi kavramlarına ilişkin literatür özetine kısaca yer verilecek ve ardından çalışmanın yöntemi hakkında bilgiler aktarılacaktır. Sonraki bölümlerde ise araştırma sürecinde elde edilen bulgular, cinsiyet ve fakülte değişkenleri üzerinden değerlendirilerek karşılaştırmalı olarak yorumlanacaktır.

\section{LITERATÜR}

Yaşam kalitesi, giriş bölümünde değinildiği üzere çok boyutlu bir kavramsal yaklaşımın tezahürü olarak ele alınmaktadır. Öyle ki yaşam kalitesi kavramının genel muhtevası içinde bir alt çalışma alanı olan kentsel yaşam kalitesi dahi birçok farklı disiplinin ortak alanı olarak ön plana çıkmaktadır. Oldukça yaygın bir kullanıma sahip olan yaşam kalitesi ile ilgili olarak literatürde bu bağlamda tanımsal ve yöntemsel bir uzlaşı olmadığı gibi kavramsal bir bütünlükten de söz edilememektedir. (Yonk vd, 2017: 72) Bu bakımdan yaşam kalitesi kavramına tekabül eden refah, sıhhat, yaşam memnuniyeti, mutluluk, iyi yaşam gibi farklı terminolojik adlandırmaların literatürde yer aldığı görülmektedir (McCrea vd, 2011: 56; Yonk ve Smith, 2018: 7). Özellikle Platon ve Aristoteles gibi Antik Yunan filozofları, modern 
döneme dair mutluluk tartışmalarının temelini oluşturmaktadırlar (White, 2006: 103). Aristoteles için mutluluk (eudaimonia), anlık bir duygu durumundan ziyade yaşamın bütünselliği içindeki iyi olma hali iken; Platon ise mutluluğu insanın nihai hedefi olarak tanımlamıştır (Russel, 2014: 1997; Michalos, 2014: 4832). Bu noktadan hareketle yaşam kalitesi olgusunun, binlerce yıllık antik bir mirasın üzerine inşa edilmiş bir kavram olduğu söylenebilir.

Yaşam kalitesinin bir kavram olarak literatürde kullanılmaya başlanması 1960'lı y1llara dayanmaktadır. Bu dönemde yaşam kalitesi, özellikle Birleşik Devletlerde, dezavantajlı gruplara yönelik bir politika yaklaşımı olarak kabul edilmektedir (Vitale, 2008: 32). Yaşam kalitesinin kentsel bağlamda incelendiği çalışmalara bakıldığında yine 1960'lı yılların ağırlıkla öne çıktığı görülmektedir. Buna karşın kentsel yaşam kalitesi araştırmalarının 1970'li yıllarla birlikte - özellikle de postfordizmin etkisiyle - literatürde önem kazandığı dikkat çekmektedir. 1970'lerde demografik ve fiziksel karakteristikler bakımdan büyüyen ve gelişen kentlerde çevre sorunları ve sosyolojik değişimler yaşanmaya başladığından o dönemdeki kentsel yaşam kalitesi çalışmalarının kent planlaması ve yönetimi konularında ağırlık kazandığı görülmektedir (Picardo-Muňiz, 2011: 365-366).

Yaşam kalitesi/kentsel yaşam kalitesi, uzun yıllar nesnel bir gerçekliğe dayanan bir olgu olarak kabul edildi. Bununla birlikte Marans ve Stimson (2011: 2-4), yaşam kalitesinin nesnel bir gerçekliğe karşılık gelmekle beraber öznel bir boyutunun da olduğunun göz ardı edilmemesi gerektiğini ileri sürmektedirler. $\mathrm{Bu}$ bakış açısından yola çıkarak yaşam kalitesi/kentsel yaşam kalitesi hakkında yapılan çalışmalar irdelendiğinde araştırmaların iki temel ölçümleme metodolojisinden (nesnel/öznel) biri ya da her ikisi üzerinden kurgulandığ anlaşılmaktadır (Land, Michalos ve Sirgy, 2012: 5).

\section{KENTSEL YAŞAM KALITESININ ÖLÇÜMLENMESİ}

Önceki başlıklarda ifade edildiği üzere yaşam kalitesi/kentsel yaşam kalitesi araştırmalarında temel olarak iki boyutlu değişken kullanılarak ölçümleme yapılmaktadır. Nesnel boyut, yaşamın daha çok dişsal koşullarına referans oluşturmaktadır. Çoğu kaynakta sosyal göstergeler olarak da adlandırılan nesnel yaşam kalitesi ölçütleri; gelir durumu, barınma, iklim, eğitim, suç, trafik gibi verilerin analiz edilmesi için kullanılmaktadır (Diener ve Suh, 1997: 191; Veenhoven, 2007; Brown, Bowling ve Flynn, 2004: 14-15). Kentsel yaşam kalitesi çalışmalarında başvurulan nesnel göstergelerin saha çalışması yapılmaksızın çoğunlukla ikincil kaynaklardan elde edildiği gözlenmektedir (Malekhosseini ve Joodaki, 2011: 1611; McCrea, Shyy ve Stimson, 2006: 79). Bunun yanında kentsel yaşam kalitesi çalışmalarında referans alınan nesnel göstergelerin bazen ölçümsel sapmalara neden olabileceği üzerinde durulmaktadır (Reto ve Garcia-Vega, 2012: 212). Örneğin suç oranlarıyla (negatif) ilgili veriler ile ekonomik görünüm (pozitif) bağlamındaki verilerin nesnelliği ve/veya güvenirliğgi tartış1labilir. $\mathrm{Bu}$ husus haricinde araştırma kapsamında belirlenen/seçilen göstergeler ya da bu göstergelerin etki faktörleri yine nesnellik sınırları bakımından benzer tartışmaları beraberinde getirmektedir (Das, 2008: 298). Ayrıca kentsel yaşam kalitesi araştırmalarında ölçümlenen nesnel boyuta, insanların çevresel etmenleri hangi şartlarda ve nasıl algıladığı ve/veya yorumladığı noktasında eleştiriler getirilmektedir. Bu nedenle yapısı gereği karmaşık bir çalışma alanı olarak kentsel yaşam kalitesi çerçevesinde öznel ya da bütünleşik göstergelerin daha güvenilir olduğu kabul edilmektedir (Brown ve diğerleri, 2004: 44).

Öznel yaşam kalitesi, insan yaşamına etki eden nesnel koşullarının ölçümlenmesini ifade etmektedir. Yaşam kalitesi/kentsel yaşam kalitesinin öznel boyutu, kişinin içinde bulunduğu bağlamla ilişkili bir analiz yöntemi olarak değerlendirilmektedir. Öznel yaşam kalitesi göstergelerini anlamaya yönelik yapılan araştırmalarının temel olarak odaklandığ 
başlıklar bireylerin mutluluk, memnuniyet ve refah düzeyleridir (Tiliouine, 2009: 115-116). $\mathrm{Bu}$ kapsamda bireylerin yaşamını ve yaşamını çevreleyen fiziksel şartları bilişsel ve duyusal yönden ele alan yöntemsel bir yaklaşım olarak öznel yaşam kalitesi, literatürde aynı zamanda kişisel göstergeler olarak da tanımlanmaktadır (Edgerton, Roberts ve von Below, 2012: 267). Kentsel yaşam kalitesi çalışmalarında referans alınan öznel göstergeler; konut, mekân, komşuluk, güvenlik, kentsel yaşam, yerel hizmetlere ilişkin his, tatmin ve algı gibi bilişsel ve duyusal süreçlerin bileşkesi olarak ifade edilmektedir (Marans ve Stimson, 2011: 3). Anlık bir duygu durumunu betimlemeye yönelik tercih edilen öznel yaşam göstergelerine, son yıllarda kentsel yaşam kalitesi araştırmalarının güvenilirliği açısından önem atfedilmektedir (Kahneman ve Krueger, 2006: 4). Bu doğrultuda öznel yaşam kalitesi göstergeleri, nesnel göstergelerden farklı olarak, verilerin birincil kaynaklardan doğrudan elde edildiği bir ölçümleme tekniği olarak değerlendirilmektedir (Veenhoven, 2000: 23). Bununla birlikte kişilerin duygu durumlarının öngörülemeyen olaylardan olumlu ya da olumsuz bir biçimde etkilenmesinin aslında anlık bir görünüm olduğu, bu durumun genel yaşam kalitesi algısını yansıtamayacağına yönelik tartışmalar da sürmektedir (Weiner, 2008). Bunun dişında öznel yaşam kalitesi göstergelerini değerlendirecek araştırmacının sahip olduğu değer yargıları, sonuca etki edebilecek bir başka unsur olarak gösterilebilir.

Sonuç olarak, kentsel yaşam kalitesinin ölçümlenmesinde nesnel ve öznel olmak üzere iki temel yaklaşım bulunmaktadır. Buradan hareketle sözü edilen bu yöntemsel yaklaşımların benimsenmesinde bazı sınırlılıkların altı yeniden çizilebilir. Nesnel ölçümlemelerde, daha çok, doğal kentsel çevre bileşenlerini genellenebilir değişkenler üzerinden açıklama eğilimi ortaya çıkarken; öznel ölçümlemeler ise, kentsel yaşamın insanlar tarafindan nasıl anlamlandırıldığına yönelmektedir. Böylelikle kentsel yaşam kalitesi çalışmalarında hem bireysel hem de bağlamsal değişkenlerin analitik bir yaklaşımla bütünsel olarak ele alınması gerekliliği ortaya çıkmaktadır (Malekhosseini ve Joodaki, 2011: 1611).

\section{YÖNTEM}

Bu çalışma, Ondokuz Mayıs Üniversitesi Güzel Sanatlar Kampüsü içerisinde yer alan; Mimarlık (Mimarlık, İç Mimarlık), Eğitim (Resim-İş Öğretmenliği, Müzik Öğretmenliği), Güzel Sanatlar (Görsel İletişim Tasarımı, Resim, Seramik-Cam) Fakülteleri ile Devlet Konservatuarının (Müzik) aktif bölümlerinde öğrenim gören üniversite öğrencilerinin kentsel yaşam kalitesine ilişkin algılarını anlamaya yönelik bir araştırmadır. Bu doğrultuda örneklemi oluşturan üniversite öğrencileriyle anket çalışması yapılmıştır ${ }^{*}$. Araştırmanın örneklemi, fakülte ve cinsiyet olmak üzere iki ana kategorizasyon üzerinden yapılandırılmıştır. Fakülteler bölüm bazında alt tabakalara ayrılmış ve buna bağlı olarak evreni temsil eden örneklem büyüklüğü \%10 olarak belirlenmiştir. Sonrasında, örnekleme dâhil olan öğrencilerin cinsiyet yönünden eşit düzeyde dağılım göstermesine dikkat edilmiştir. Böylelikle evreni meydana getiren 1351 öğrenci içinden tüm fakülteler, bölümler ve sınıflar için \%10'luk bir örneklem oranı neticesinde basit tesadüfi yöntemle 136 öğrenciye ulaşılmıştır.

Yaşam kalitesi/kentsel yaşam kalitesinin ölçümlenmesine ilişkin olarak literatürde birçok farklı gösterge ve yöntem kullanılmaktadır. Bu çalışmanın anket soruları, kentsel yaşam kalitesi literatürünün referans çalışmalarından; "Investigating Quality of Urban Life: Theory, Methods and Empirical Research"in editörleri Marans ve Stimson'un (2011: 3) birlikte çerçevelendirdiği kentsel yaşam kalitesi göstergeleri temel alınarak - araştırmanın genel kurgusuna uygun olarak yeniden düzenlenerek - hazırlanmıştır.

\footnotetext{
*Eğitim Fakültesi bünyesinde toplam 26 aktif bölüm bulunmaktadır. Bu bölümlerin 24 tanesi üniversitenin merkez kampüsünde faaliyet gösterirken, yalnızca Resim-İşv ve Müzik Öğretmenliği Bölümleri Güzel Sanatlar Kampüsünde yer almaktadir.
} 


\section{BULGULAR VE TARTIŞMA}

Çalışma sahası olarak tercih edilen Ondokuz Mayıs Üniversitesi Güzel Sanatlar Kampüsü, Samsun'un iki merkez ilçesinin (Atakum, İlkadım) kesişme noktasında yer almaktadır. Bu haliyle Ondokuz Mayıs Üniversitesinin - Merkez (Kurupelit) Kampüsü de dâhil olmak üzere - en merkezi kampüsü konumundadır**. Buradan hareketle aynı zamanda araştırmanın evrenini oluşturan Güzel Sanatlar Kampüsünün, öğrencilerin kent ile temasının kurulması ve bu temasın sürekliliği açısından avantajlı bir konumda olduğu söylenebilir. $\mathrm{Bu}$ bağlamda Samsun'da yaşam kalitesinin üniversite öğrencileri tarafından nasıl algılandığı ve/veya yorumlandığını anlamaya yönelik tasarlanan bu çalışmada uygulama sahası olarak Güzel Sanatlar Kampüsü seçilmiştir.

Saha çalışması, Ondokuz Mayıs Üniversitesi Güzel Sanatlar Kampüsünde lisans düzeyinde öğrenim gören üniversite öğrencilerinin öznel yaşam kalitesi algılarının uygulanan anket çalışması ile betimlendirilmesi üzerine dizayn edilmiştir* . Buradan hareketle örneklem grubuna ilk olarak gelir durumu ile kentsel yaşam kalitesi arasındaki ilişki sorulmuştur. Verilen tüm cevaplar bir arada değerlendirildiğinde gelir durumu ile kentsel yaşam kalitesi arasında \%81,6 oranında güçlü bir ilişki olduğu ortaya çıkmıştır. Gelir durumu ile kentsel yaşam kalitesi arasında kısmen de olsa bir ilişki olduğunu düşünenler de bu orana eklendiğinde nedensellik ilişkisinin \%94,8'e ulaştığ 1 görülmektedir. Tüm veriler kategorik olarak çözümlendiğinde cinsiyet bağlamında kayda değer farklılaşma gözlenmemekle birlikte Devlet Konservatuarı $(\% 25)$ ve Güzel Sanatlar Fakültesi $(\% 21,9)$ öğrencilerinin gelir durumu ile kentsel yaşam kalitesi arasında görece keskin bir bağ kurmadıkları söylenebilir (Grafik 1).

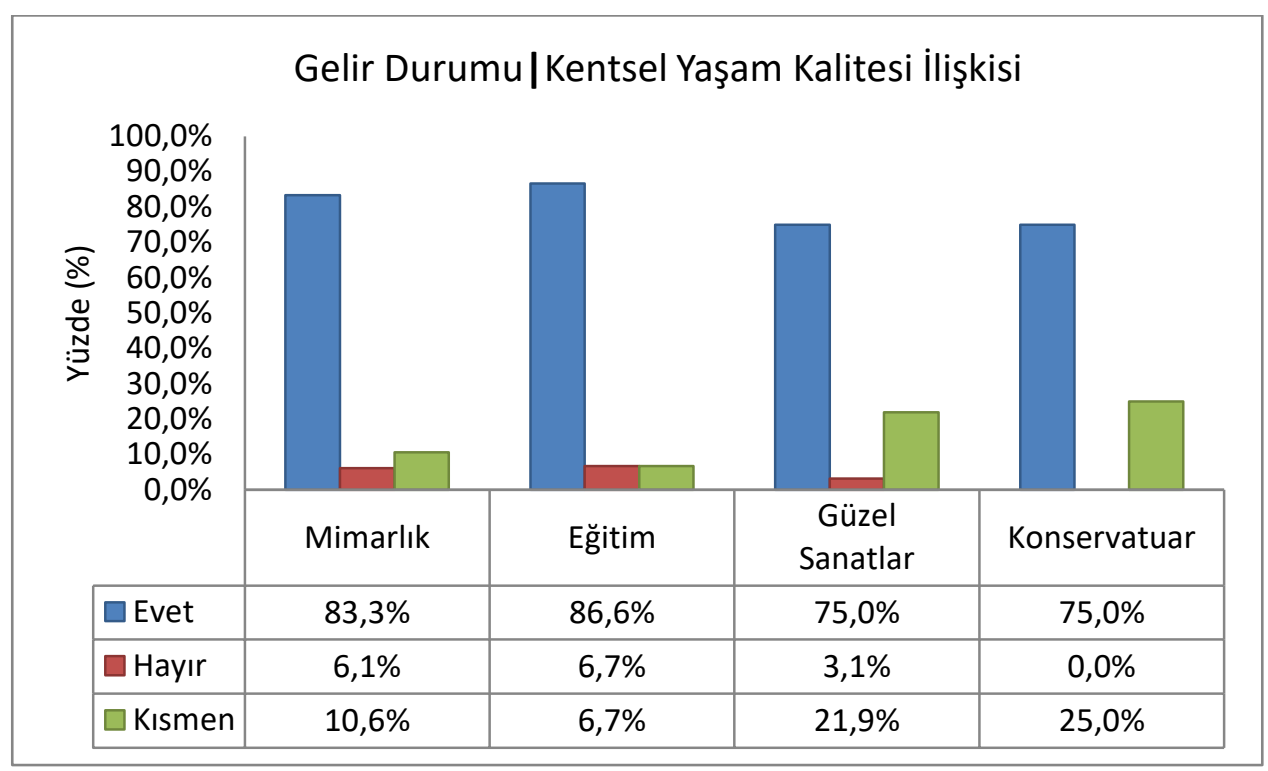

Grafik 1: Gelir Durumu | Kentsel Yaşam Kalitesi İlişkisi.

Gelir durumu ile kentsel yaşam kalitesi arasındaki ilişkiyi anlamaya yönelik örneklem grubuna yöneltilen bir önceki soruyu takiben bu defa kentsel hayat pahalılığına ilişkin bir soru sorulmuştur. Soruya yanıt verenlerin yalnızca \%22,8'i Samsun'u pahalı bir kent olarak nitelendirmiştir. Samsun'u pahalı bir kent olarak yorumlayanlar, cinsiyet yönünden dengeli

\footnotetext{
** Ondokuz Mayıs Üniversitesi 4 farklı yerleşkeye sahiptir. Bunlar: Kurupelit, Güzel Sanatlar, Mustafa Kemal Güneşdoğdu, Bafra kampüsleridir.

*Ondokuz Mayıs Üniversitesi Güzel Sanatlar Kampüsü içerisinde; Mimarlık, Eğitim, Güzel Sanatlar Fakülteleri ile Devlet Konservatuarının dışında bir de Samsun Meslek Yüksekokulu yer almaktadır. Evreni meydana getiren birimler içinde tüm sınıflar eşit oranda temsil edildiğinden karşılaştırmalı analizlerin tutarlılığı bakımından ön lisans (2 yıl) düzeyinde eğitim veren Samsun Meslek Yüksekokulu saha çalışmasının kapsamı dışında tutulmuştur.
} 
bir dağılım gösterirken (fark: \%1,1), farklı fakültelerde öğrenim gören öğrenciler arasındaki dağılımın heterojen yapısı dikkat çekmektedir. Buna mukabil Samsun'un pahalı bir kent olmadığını düşünen erkek öğrencilerin oranı kız öğrencilere göre nispeten daha yüksektir (fark: \%5,8).

Kentsel hayat pahalılığına ilişkin yöneltilen soruya verilen yanıtlar fakülteler bazında değerlendirildiğinde Mimarlık Fakültesi öğrencileri ile Devlet Konservatuarı öğrencileri arasında derin bir algısal farklılığın olduğu saptanmıştır (fark: \%54,9) (Grafik 2). Mimarlık Fakültesinde öğrenim gören öğrencilerin \%78'i Samsun'da kırtasiye ücretlerinin yüksekliğine dikkat çekerken, Konservatuar öğrencilerinin \%75'i kent içi ulaşım ücretlerine gönderme yapmaktadır. Bununla birlikte Mimarlık öğrencilerinin yalnızca \%36,2'si kent içi ulaşımın pahalılığından yakınmaktadır ${ }^{*}$. Bu noktada cinsiyet bağlamında bir farklılaşmanın da olduğu gözlenmiştir. Mimarlıkta okuyan erkek ve kız öğrenciler arasında ulaşım ücretlerinin yüksekliği bakımından \%9,9 oranında bir fark bulunmaktadır. Bu doğrultuda Mimarlık Fakültesinde öğrenim gören kız öğrenciler, erkek öğrencilere göre ulaşım ücretlerinin daha pahalı olduğunu düşünmektedir. Devlet Konservatuarında okuyan öğrenciler arasında bu kapsamda belirgin bir farklılığın bulunmadığı sonucuna ulaşılmıştır.

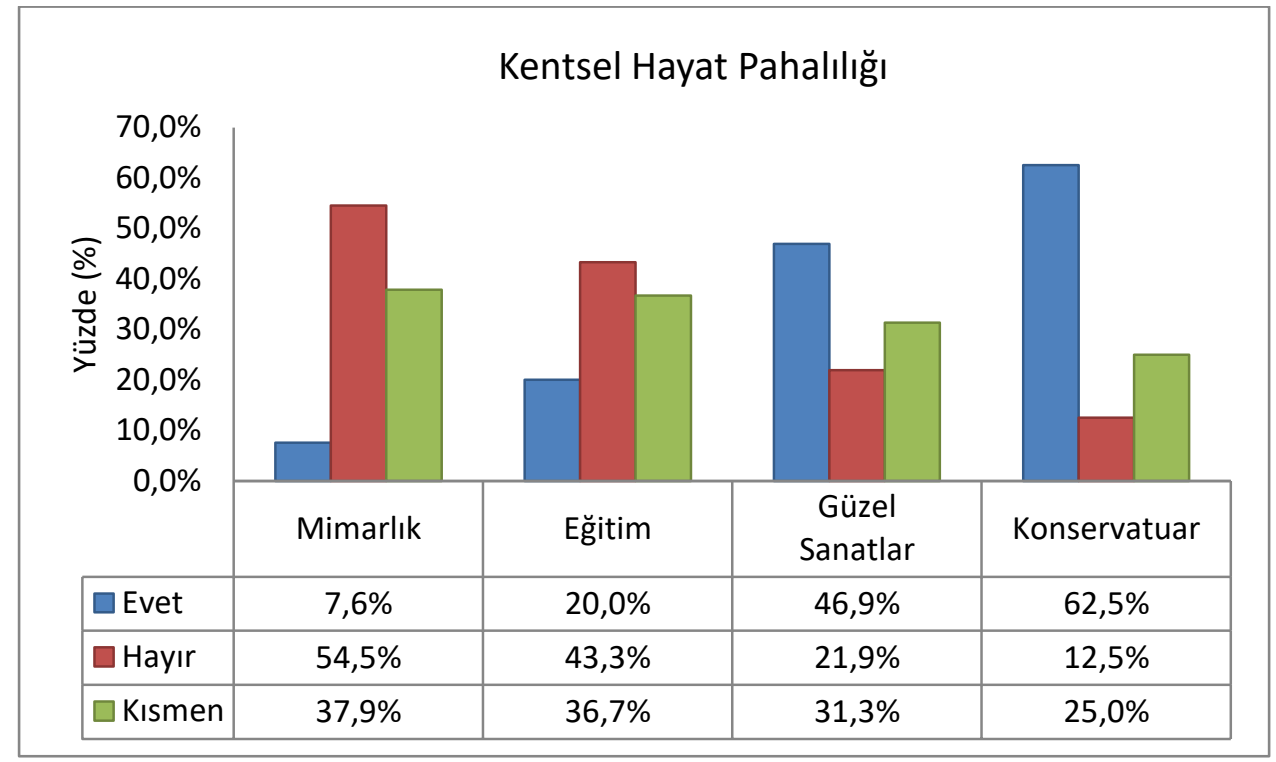

Grafik 2: Kentsel Hayat Pahalılı̆̆1.

Öğrencilerin kent içinde ulaşımlarını nasıl sağladığını anlamaya yönelik sorulan soru çerçevesinde tramvay \%45,3 ile dominant ulaşım aracı olarak ön plana çıkmaktadır. Tramvayı $\% 33,1$ ile minibüs/dolmuş takip etmektedir. Otobüs $(\% 17,7)$, yaya $(\% 15,9)$ ve özel araç $(\% 15,3)$ seçenekleri birbirine yakın oranlarda dağılırken en az tercih edilen ulaşım aracının ise $\% 1,2$ ile taksi olduğu anlaşılmaktadır (Grafik 3).

“Samsun'da ulaşımınızı nasıl sağlıyorsunuz?" sorusuna verilen yanıtlar içinde kız öğrencilerin erkek öğrencilere oranla tramvayı çok daha yoğun olarak kullandığı tespit edilmiştir (fark: \%6,1). Diğer ulaşım araçları bağlamında cinsiyet yönünden anlamlı başka bir ayrışma gözlenmemiştir.

\footnotetext{
*Örneklem grubunun bu soruda kentsel hayat pahalılığına ilişkin çoklu görüş bildirmesine olanak sağlanmıştır.
} 


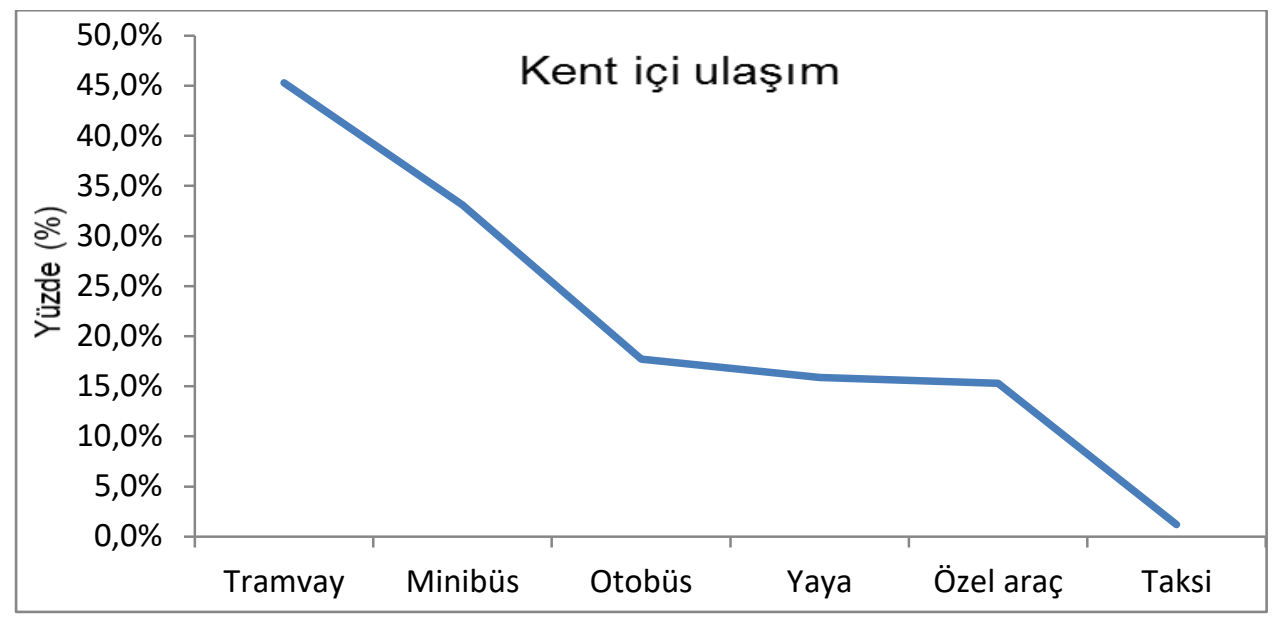

Grafik 3: Kent İçi Ulaşım.

Araştırmaya konu olan öğrenci grubunun \%71,7'si günlük yaşamında toplu ulaşım araçlarını tercih ettiğini ifade ederken, bu bağlamdaki memnuniyet oranı \%28,5 olarak belirlenmiştir. Tüm yerel hizmetler içerisindeki en yüksek memnuniyet düzeyine tekabül eden kent içi toplu ulaşım hizmetlerinde Mimarlık Fakültesi öğrencileri bu anlamda başı çekmektedir $(\% 21,4)$. Toplu ulaşımdaki memnuniyet oranını, \%23,2 ile çevre düzenlemeleri, $\% 19,6$ ile de temizlik hizmetleri takip etmektedir.

Yerel hizmetlerdeki memnuniyetsizlik düzeyine bakıldığında ise, ilk sırada \%40,4 ile altyapı/yol çalışmaları yer almaktadır. İkinci sırada \%35,3 ile kent içi toplu ulaşım, üçüncü sirada ise \%22,2 ile temizlik hizmetleri gelmektedir ${ }^{*}$.

Elde edilen tüm veriler 1şığında örneklem grubunda yerel hizmetler bakımından genel bir memnuniyetsizlik durumunun olduğu söylenebilir. Yerel hizmetlerden memnuniyet düzeyi \%18 olarak görünmektedir (Grafik 4). Genel memnuniyetin en yüksek oranda ortaya çıktığı birim Eğitim Fakültesi $(\% 20,7)$ olurken, memnuniyetsizliğin en yüksek oranda Devlet Konservatuarı $(\% 56,3)$ öğrencilerinde kendini gösterdiği sonucuna ulaşılmıştır.

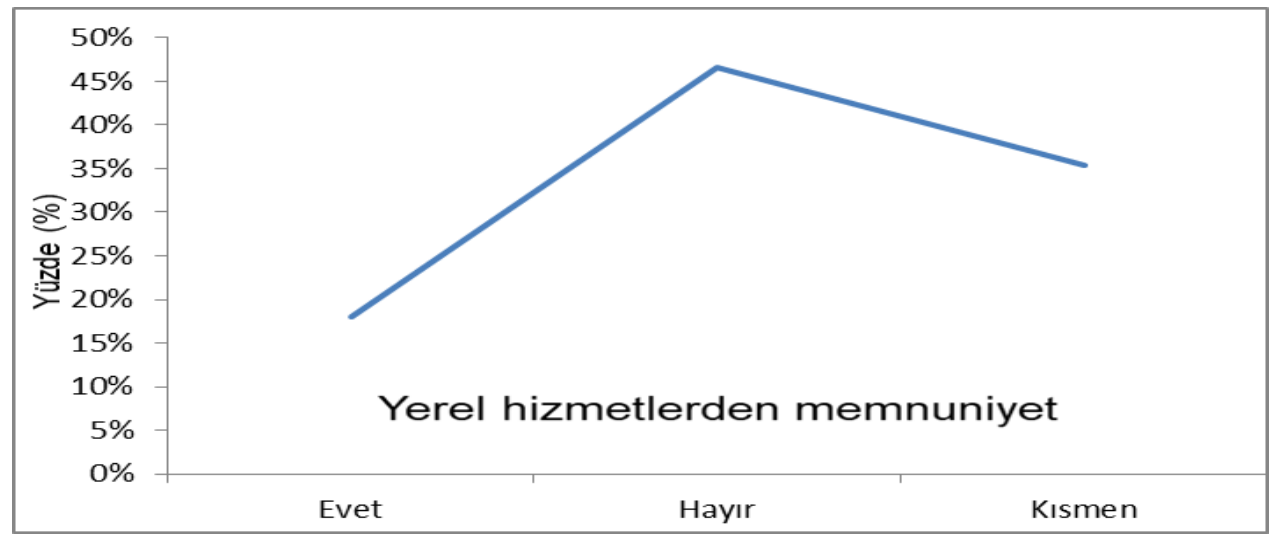

Grafik 4: Yerel Hizmetlerden Memnuniyet.

\footnotetext{
*Memnuniyetsizlik oranlarının memnuniyet oranlarından daha yüksek olması soruya verilen yanıtların yoğunluğundan kaynaklanmaktadır. Yerel hizmetlerdeki memnuniyetsizliğe ilişkin sorulan soruya \%75,5 nispetinde yanıt verilmiştir. Memnun olunan yerel hizmetlere ilişkin sorulan soruda ise bu oran \%42,7'dir.
} 
Ondokuz Mayıs Üniversitesi Güzel Sanatlar Kampüsünde öğrenim gören öğrencilerin yerel hizmetlerden memnuniyet düzeyinin anlamlandırılmaya çalışıldığ hizmetler ile sanatsal/kültürel faaliyetler arasında oldukça düşük bir algısal belirginlik durumu gözlemlenmiştir. Öğrencilerin sadece \%5,3’ü yerel hizmetler bağlamında sanatsal/kültürel faaliyet memnuniyeti ya da memnuniyetsizliği bildirmiştir. Bununla birlikte 'Kentte düzenlenen sanatsal/kültürel etkinlikleri yeterli buluyor musunuz?' sorusunu örneklem grubunun tamamı yanıtlarken yöneltilen bu soruya evet diyenlerin oranı $\% 18,3$ olarak ölçülmüştür*. Tüm bu veriler bir arada değerlendirildiğinde sanatsal/kültürel faaliyetlerin öğrenciler tarafından yerel bir hizmet olarak algılanmadığı sonucuna varılabilir.

Öğrencilerin sanatsal/kültürel etkinliklere katılımına ilişkin veriler incelendiğinde her birinin en az bir aktiviteye katıldığı anlaşılmaktadır. Sanatsal/kültürel faaliyetlere katılım bakımından oransal dağılımda \%76 ile sinema başta gelmektedir. Sinemayı \%09,2 ile konser, $\% 6,1$ ile de tiyatro takip etmektedir. Konservatuar öğrencileri, bu noktada diğerlerinden farklılaşmaktadır. Sinema, tüm fakülteler için en fazla tercih edilen aktivite konumunda iken, Devlet Konservatuarında öğrenim gören öğrenciler \%87,5 ile konsere ilgi göstermektedir. En düşük seviyede gerçekleşen sanatsal/kültürel aktivitelerin ise, opera $(\% 4,9)$ ve müze ziyareti $(\% 3,7)$ olduğu sonucuna ulaşılmıştır.

Araştırmanın örneklemini oluşturan öğrenci grubunun çoğunluğu, boş vakitlerini açık alanlarda $(\% 58,3)$ geçirmeyi tercih ettiğini dile getirmiştir. Bu bağlamda cinsiyet ve fakülte yönünden dikkate değer bir farklılık gözlenmemiştir. Öğrencilerin kapalı alanlarda ilk tercihleri, kafe/restoran $(\% 16,5)$ olurken; açık alanlarda, \%40,9 ile sahil ön plana çıkmaktadır.

Boş vakitlerini çoğunlukla açık alanlarda değerlendirdikleri anlaşılan örneklem grubunun \%49,7'si, Samsun'un yaşanabilir bir iklime sahip olduğunu ifade ederken, aksini düşünenlerin oranı \%20,1 olarak gerçekleşmiştir. Samsun'u iklim yönünden yaşanabilir bulmayanların ağırlıklı olarak Samsunlu olması $(\% 53,8)$, araştırmanın dikkat çekici bulgularından biri olarak değerlendirilebilin**. İklimsel yaşanabilirlik ile ilgili soruya verilen tüm yanıtlar bir arada değerlendirildiğinde öğrencilerin öne çıkardığı kentler İzmir $(\% 26,9)$ ve Antalya (\%10,3) olmuştur.

Kentsel hayata katılım üzerinden şimdiye kadar daha somut göstergelerin anlamlandırılmaya çalışıldığı bu noktada, görece öznellik içeren kentsel canlılık algısı saptanmaya çalışılmıştır. Evreni temsil eden öğrenci grubuna sorulan "Samsun canlı bir kent midir?" sorusuna ağırlıklı olarak kısmen yanıtı verilmiştir $(\% 43,6)$. Samsun'u canlı bir kent olarak tanımlayanların oranı \%37,1'dir. Fakülteler arasında belirgin farklılıklar bulunmamakla birlikte cinsiyet bakımından ayırt edici bir durumun ortaya çıktığı ifade edilebilir $^{* * *}$. Erkek öğrencilerin Samsun'da kentsel canlılık algısı, kız öğrencilere göre daha baskın olarak ortaya çıkmaktadır (fark: \%27) | (Grafik 5).

\footnotetext{
*Hayır: \%41,2; K1smen: \%40,5

${ }^{* *}$ Samsunluları karasal iklimden gelenler takip etmektedir $(\% 30,8)$.

Samsun'un yaşanabilir bir iklime sahip olmadığını düşünen Samsunlu öğrencilerin tüm örneklem grubu içerisindeki Samsunlulara oran $1 \% 21,2$ 'dir.

*** Eğitim Fakültesi öğrencilerinin Samsun'a ilişkin kentsel canlılık algısı diğer fakültelerde öğrenim görenlere oranla görece düşük düzeydedir (fark: \%5).
} 


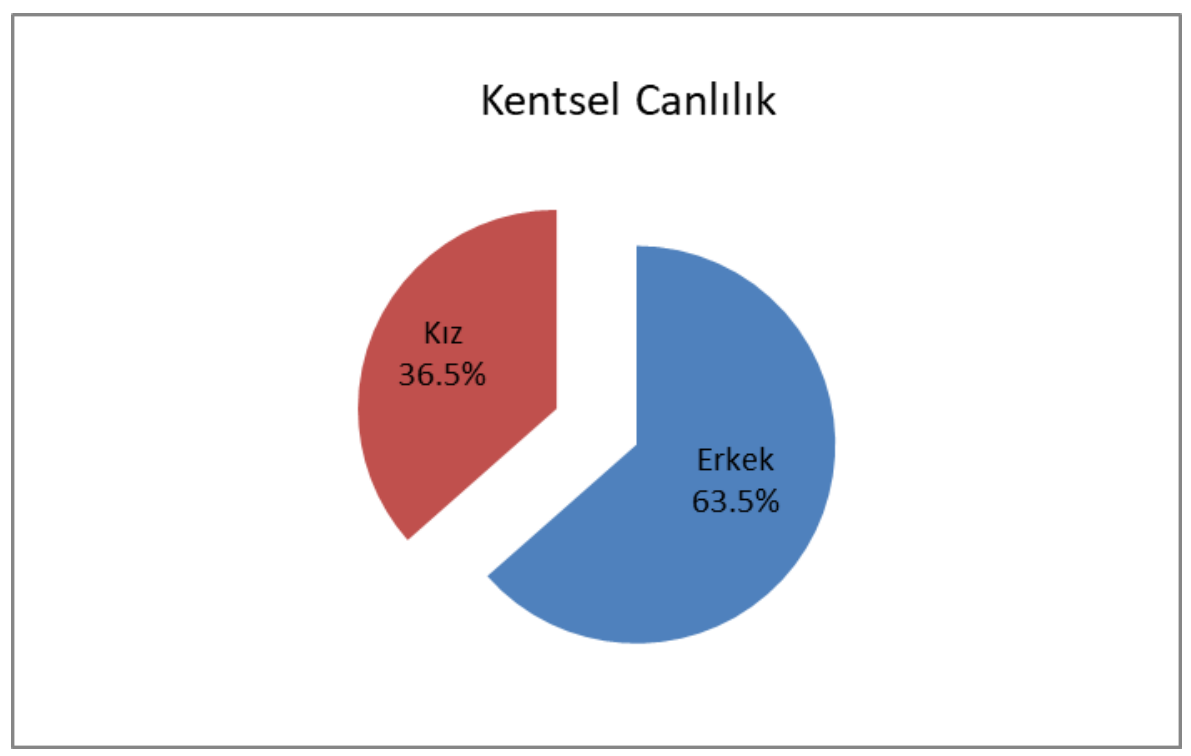

Grafik 5: Kentsel Canlılık.

Öznel yaşam kalitesi göstergelerinden biri olarak kentsel kozmopolitlik sorusuna öğrencilerin \%62'si evet yanıtını vermiştir. Öznel algılama biçimlerinin etkili olduğu ve buna bağlı olarak farklı yorumların ortaya çıkması muhtemel kentsel kozmopolitlik olgusu bağlamında cinsiyet ve fakülte değişkenleri açısından dengeli bir dağılımın olduğu dikkat çekmektedir. Yine kentsel yaşam kalitesi bağlamında ele alınan kozmopolitlik ve canlılık olguları arasında güçlü bir ilişkinin çıkmamış olması, dikkat çekici bir başka önemli nokta olarak yorumlanabilir.

Ondokuz Mayıs Üniversitesi Güzel Sanatlar Kampüsünde eğitim hayatını sürdüren farklı fakültelere mensup öğrencilere yöneltilen kozmopolitlik ve kentsel canlılığa dair soruların ardından, kentsel yaşam kalitesinin önemli bir başka bileşeni olan güvenlik algısı üzerinde durulmuştur. Samsun'un güvenli bir kent olmadığını düşünenler \%35,6 ile ilk sırada yer almaktadır. Dağılım göstergelerinde kentin kısmen güvenli olduğunu belirtenler \%34,3 oranıyla, hayır yanıtını verenleri izlerken; "Samsun güvenli bir kenttir" diyenlerin oranı \%30,1 olarak tespit edilmiştir. Elde edilen veriler, fakülteler temelinde çözümlendiğinde kentsel güvenlik algısının Eğitim Fakültesi öğrencilerinde en düşük; Konservatuvar öğrencilerinde ise, en yüksek seviyeye ulaştığı belirlenmiştir (Grafik 6). Bu noktada cinsiyet bağlamında bir ayrımın ortaya çıktığı söylenebilir. Kız öğrenciler, erkeklere oranla Samsun'u daha güvenli bir kent olarak görmektedir (fark: \%5,8). Erkek öğrencilerin ise, \%3,4 oranlık bir farkla kenti daha güvensiz bulduğu sonucuna ulaşılmıştır. Ortaya çıkan bu tablodan hareketle kız öğrencilerin kentsel güvenlik algısının erkek öğrencilere göre daha güçlü olduğu söylenebilir. 


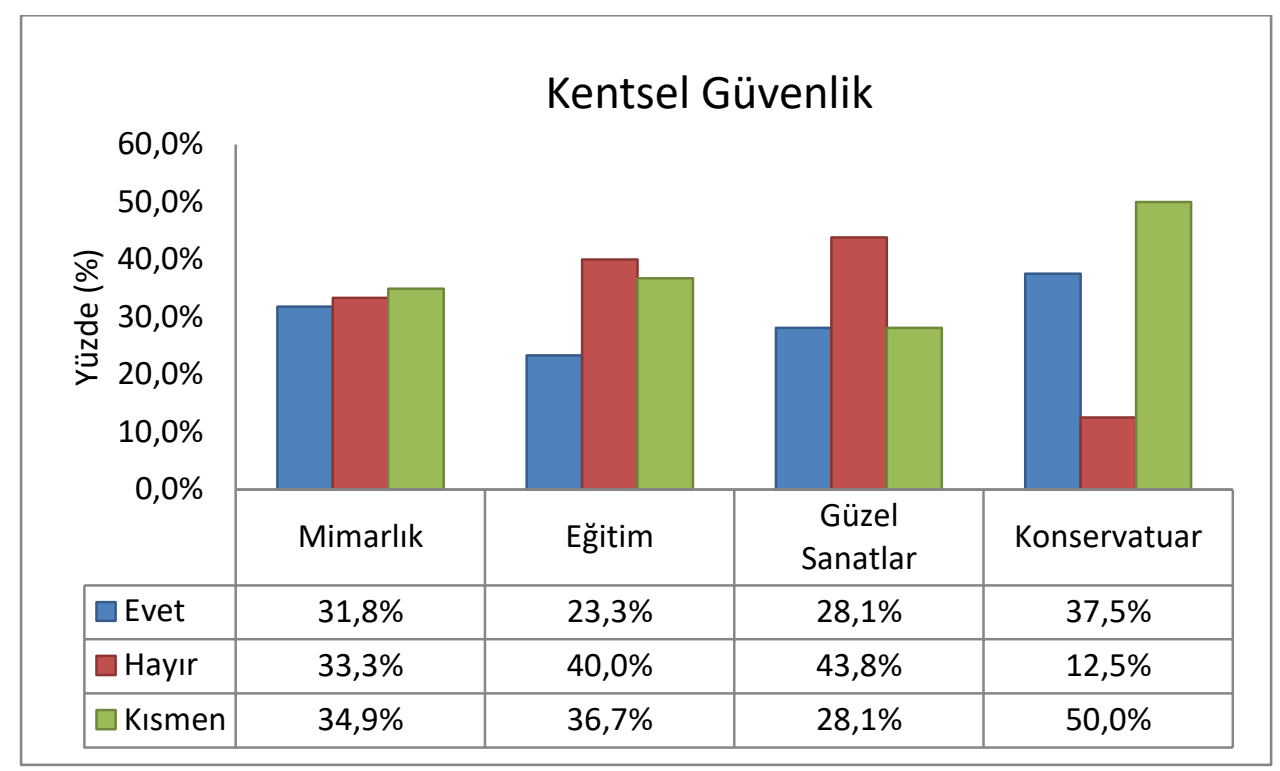

Grafik 6: Kentsel Güvenlik.

Öğrencilerin kentsel güvenlik ile kentsel canlılığa ilişsin algıları arasında istatistiksel bir anlamlılıktan söz edilebilir. Şöyle ki; Samsun'u canlı bir kent olarak betimlemeyenler $(\% 37,1)$ ile Samsun'un güvenli bir kent olmadığ 1 düşüncesinde olanlar $(\% 35,6)$ arasında \%1,5 puanlık bir fark bulunmaktadır. Buradan yola çıkarak - bu çalışma kapsamında - kentsel yaşam kalitesi algısını belirleyen güvenlik ve canlılık faktörleri arasında anlamlı bir etkileşim olduğu sonucuna varılabilir.

\section{SONUÇ}

Çalışmanın başında vurgulandığı üzere yaşam kalitesi çok boyutlu ve karmaşık bir olgudur. Bu bağlamda ele alınan göstergeler zamana, mekâna, demografik profile hatta yaşam kalitesini anlama biçimine göre değişkenlik gösterebilmektedir. Araştırma bulgularının değerlendirildiği kısımda görüldügüü üzere, genel yaşam kalitesi algısını biçimlendiren faktörler, değişkenlere bağlı olarak farklı yorumlanabilmektedir. Bu noktada, araştırma sürecinde elde edilen bir başka bulgu örnek olarak gösterilebilir. Araştırmaya katılan öğrencilerin \%74,8 gibi büyük bir çoğunluğu şehir suyunu içmediğini belirtmiştir. Bununla birlikte şehir suyunu tüketenlerin \%12,9'u arıtma işlemi yaptığına dikkat çekmiştir. Samsun $\mathrm{Su}$ ve Kanalizasyon İdaresi'nin (SASKİ) günlük olarak analiz ettiği şehir suyu kalite parametreleri incelendiğinde şehir suyunun tüm kimyasal değerler dâhilinde içilebilir olduğu raporlanmıştır (SASKİ, 2019).

Elde edilen tüm bu veriler 1şığında, gerçeklik algısının, yaşam kalitesi üzerinde aslında ne kadar etkili olabileceği görülmektedir. Dolayısıyla salt mutlak gerçeklikler temelinden hareketle yaşam kalitesinin ele alınamayacağının altı çizilebilir. Bu nedenle çalışmada nesnel gerçekliğin nasıl algılandığı üzerinden kentsel yaşam kalitesi göstergelerinin yorumlanması amaçlanmıştır.

Tartışma başlığ 1 altında analiz edilen bulgular, genel olarak değerlendirildiğinde gelir durumu ile kentsel yaşam kalitesi arasında yüksek oranda doğrusal bir bağ olduğu dikkat çekmektedir. Bununla birlikte örneklem grubunun genel itibarıyla Samsun'u pahalı bir kent olarak algılamadığı sonucundan hareketle kente dair bir yaşam kalitesi perspektifinde bulunulabilir. Buna ek olarak öğrencilerin \%63,8 gibi önemli bir çoğunluğu Samsun'un geleceği hakkında olumlu düşüncelere sahip olduğunu belirtmiştir. Kentin geleceğine yönelik 
olumlu bakış açısına sahip olanların \%49,4'ünün Samsunlu olma(ma)sı bu noktada önemli bir sonuç olarak yorumlanabilir. Çalışmanın örneklemini oluşturan öğrenciler tüm bu soruların ardından "Yükseköğrenim sürecini tamamladıktan sonra yaşamınızı Samsun'da sürdürmeyi düşünüyor musunuz?" sorusuna \%45,4 oranında evet şeklinde yanıt vermesi, yine kentsel yaşam kalitesi perspektifi dâhilinde mülahaza edilebilir. Öğrenim hayatını tamamladıktan sonra Samsun'da yaşamayı düşünmeyen \%54,6'l1k öğrenci grubunun; "Nerede yaşamak isterseniz?" sorusuna ise ağırlıklı olarak İstanbul $(\% 27,3)$ ve İzmir $(\% 18,2)$ yanıtını vermesi istihdam olanakları ile kentsel yaşam kalitesi arasındaki ilişki bağlamında yorumlanabilir. Son olarak, Samsun'da yaşamayı düşünmeyenlerin \%47,7'sinin Samsunlu olması dişında \%41,1'lik bir Samsunlu olmayan kesimin de yaşamlarını Samsun'da devam ettirmeyi düşünmesi araştırmanın bu noktadaki sonucu bakımından önemli görülmektedir.

\section{KAYNAKÇA}

Beritan, S. C. (2014), Küresel Kentler Bağlamında Yaşam Kalitesi Göstergelerine Kalitatif Bir Bakış: İstanbul - New York Karşılaştırması. Yayımlanmamış Doktora Tezi, İstanbul: Marmara Üniversitesi Sosyal Bilimler Enstitüsü.

Brown, J., A. Bowling ve T. Flynn (2004), Models of Quality of Life: A Taxonomy, Overview and Systematic Review of the Literature, European Forum on Population Ageing Research.

Das, D. (2008), Urban Quality of Life: A Case Study of Guwahati, Social Indicators Research. 38.4, 297-310.

Diener, E. ve E. Suh (1997), Measuring Quality of Life: Economic, Social, and Subjective Indicators. Social Indicators Research, 40.1-2, 189-216.

Edgerton, D. J., L. W. Roberts ve S. von Below (2012), Education and Quality of Life", K. C. Land, A. C. Michalos ve M. J. Sirgy (ed.), Handbook of Social Indicators and Quality of Life Research içinde, Dordrecht: Springer, 265-296.

Kahneman, D. ve A. B. Krueger (2006), Developments in the Measurement of Subjective Well-Being, Journal of Economic Perspectives, 20.1, 3-24.

Land, C. K., A. Michalos ve M. J. Sirgy (2012), Prologue: The Development and Evolution of Research on Social Indicators and Quality of Life (QOL), K. C. Land, A. C. Michalos ve M. J. Sirgy (ed.), Handbook of Social Indicators and Quality of Life Research içinde, Dordrecht: Springer, 1-22.

Lotfi, S., A. Faraji, H. Hataminejad ve A. Pourahmad (2011), A Study of Urban Quality of Life in a Developing Country, Journal of Social Sciences, 7.2, 232-240.

Malekhosseini, A. ve H. Joodaki (2011), Review of Urban Life Quality in Separation of Localities in Iran Case Study: Noorabad City, Journal of Basic and Applied Scientific Research, 1.10, 1611-1622.

Marans, R. W. ve R. Stimson (2011), An Overview of Quality of Urban Life, R. W. Marans ve R. Stimson (ed.), Investigating Quality of Urban Life: Theory, Methods and Empirical Research içinde, Dordrecht: Springer, 1-29.

Massam, H. B. (2002), Quality of Life: Public Planning and Private Living, Progress in Planning, 58.3, 141-227.

Michalos, A. C. (2014), Plato, A. C. Michalos (ed.), Encyclopedia of Quality of Life and Well-Being Research içinde, New York: Springer, 4826-4833. 
McCrea, R., T. K. Shyy ve R. Stimson (2006), What is the Strength of the Link Between Objective and Subjective Indicators of Urban Quality of Life?, Applied Research in Quality of Life, 1.1, 79-96.

McCrea, R., R. W. Marans, R. Stimson ve J. Western (2011), Subjective Measurement of Quality of Life Using Primary Data Collection and the Analysis of Survey Data, R. W. Marans ve R. Stimson (ed.), Investigating Quality of Urban Life: Theory, Methods and Empirical Research içinde, Dordrecht: Springer, 55-75.

Picardo-Muňiz, A. (2011), The Role of Diseconomies of Transportation and Public Safety Problems in the Measurement of Urban Quality of Life, Applied Research in Quality of Life, 6.4, 363-386.

Reto, F. ve J. Garcia-Vega (2012), Quality of Life in Mexico: A Formative Measurement Approach, Applied Research Quality Life, 7.3, 223-238.

SASKİ (2019), Su Analiz Raporları, https://www.saski.gov.tr/suanalizraporlari/ (Erişim Tarihi: 10.02.2019).

Russel, D. (2014), Eudaimonia, A. C. Michalos (ed.), Encyclopedia of Quality of Life and Well-Being Research içinde, New York: Springer, 1996-1999.

Tiliouine, H. (2009), Stability and Change in National and Personal Wellbeing in Algeria: A Case Study of a Developing Country in Transition, V. Møller ve D. Huschka (ed.), Quality of Life and the Millennium Challenge içinde, Dordrecht: Springer, 115-138.

Türkoğlu, H., F. Bölen, P. K. Baran ve F. Terzi (2011), Measuring Quality of Life in Istanbul, R. W. Marans ve R. Stimson (ed.), Investigating Quality of Urban Life: Theory, Methods and Empirical Research içinde, Dordrecht: Springer, 209-231.

Veenhoven, R. (2000), The Four Qualities of Life: Ordering Concepts and Measures of the Good Life, Journal of Happiness Studies, 1.1, 1-39.

Veenhoven, R. (2007), Subjective Measures of Well-being, M. McGillivray (ed.), Human Well-being: Concept and Measurement, London: Palgrave McMillan, 214-239.

Vitale, S. A. (2008), City of Disorder: How the Quality of Life Campaign Transformed New York Politics, New York: New York University Press.

Weiner, E. (2008), The Geography Of Bliss, London: Black Swan.

White, N. P. (2006), A Brief History of Happiness, Oxford: Blackwell Publishing.

Yonk, M. R., J. T. Smith ve A. R. Wardle (2017), Building a Quality of Life Index, A. A. V. Boas (ed.), Quality of Life and Quality of Working Life içinde, Rijeka: InTech, 71-96.

Yonk, M. R. Ve J. T. Smith (2018), Politics and Quality of Life: The Role of Well-Being in Political Outcomes, Cham: Springer. 